\title{
PENGARUH PUPUK KOMPOS KOTORAN KELELAWAR TERHADAP PERTUMBUHAN DAN HASIL TANAMAN JAGUNG MANIS (Zea mays saccharata Sturt) PADA TANAH PMK
}

\author{
Nining Sri Sukasih \\ Fakultas Pertanian Universitas Kapuas Sintang \\ email : niningskasih@g.mail.com
}

\begin{abstract}
Abstrak: Pertumbuhan serta hasil tanaman Jagung Manis di Kabupaten Sintang perlu ditingkatkan antara lain dengan pemberian pupuk kompos kotoran kelelawar. Penelitian ini bertujuan untuk mengetahui pengaruh pupuk kompos kotoran kelelawar terhadap pertumbuhan dan hasil tanaman jagung pada tanah PMK dan dosis pupuk kompos kotoran kelelawar yang akan menghasilkan pertumbuhan serta hasil jagung tertinggi pada tanah PMK.Penelitian ini menggunakan metode Rancangan Acak Kelompok dengan pupuk kompos kotoran kelelawar sebagai perlakuan terdiri dari Lima taraf perlakuan yaitu $\mathrm{N}_{0}=$ tanpa pupuk kompos kotoran kelelawar, $\mathrm{N}_{1}=1 \mathrm{~kg}$ per petak percobaan, $\mathrm{N}_{2}=2 \mathrm{~kg}$ per petak percobaan, $\mathrm{N}_{3}=3 \mathrm{~kg}$ per petak percobaan, dan $\mathrm{N}_{4}=4 \mathrm{~kg}$ per petak percobaan. Data hasil pengamatan dianalisis dengan analisis ragam, dan dilanjutkan dengan uji BNJ.Hasil penelitian menunjukkan bahwa kompos kotoran kelelawar berpengaruh nyata terhadap pertumbuhan dan hasil tanaman jagung yang ditandai dengan tinggi tanaman, diameter batang dan berat tongkol. Pemberian pupuk kompos kotoran kelelawar $4 \mathrm{~kg}$ per $\mathrm{m}^{2}$ menghasilkan tinggi tanaman 171,5 cm, diameter batang tanaman 1,38, dan berat tongkol 149,25 gram per tanaman.
\end{abstract}

Kata Kunci: Pupuk Kompos Kotoran Kelelawar , jagung manis, pertumbuhan, hasil dan Tanah PMK.

\section{PENDAHULUAN}

Jagung manis (Zea mays saccharata Sturt) merupakan salah satu bahan pangan yang penting karena biji jagung banyak mengandung gizi dan kaya serat tetapi produksi tanaman jagung di Kabupaten Sintang rendah. Hal ini diketahui dari Badan Pusat Statistik Kabupaten Sintang (2015:10), rata- rata produksi jagung di Kabupaten Sintang adalah 1,2 ton/ha.

$$
\text { Salah satu penyebab }
$$
rendahnya produksi jagung manis di Kabupaten Sintang diduga karena sebagian besar petani membudidayakan tanaman di tanah Podsolik Merah Kuning (PMK), karena tanah ini memilki kandungan bahan organik yang rendah dan keasaman tanah yang cukup tinggi 
Pengaruh Pupuk Kompos Kotoran Kelelawar Terhadap Pertumbuhan Dan Hasil Tanaman Jagung Manis (Zea mays saccharata Sturt) Pada Tanah PMK

sehingga menyebabkan pertumbuhan maupun hasil tanaman tidak optimal. Salah satu untuk meningkatkan hasil tanaman pada tanah PMK adalah dengan memberikan bahan organik seperti pupuk kompos kotoran kelelawar.

Pupuk Kompos kotoran kelelawar yang digunakan sangat didukung dengan ketersediaanya yang cukup banyak dilihat dari gua yang menjadi habitat kelelawar sekaligus sebagai penghasil kompos kotoran kelelawar.

Penelitian ini bertujuan untuk: 1. untuk mengetahui pengaruh pupuk kompos kotoran kelelawar terhadap pertumbuhan dan hasil tanaman jagung pada tanah PMK. 2. Untuk mengetahui dosis pupuk kompos kotoran kelelawar yang akan menghasilkan pertumbuhan serta hasil jagung tertinggi pada tanah PMK.

\section{METODOLOGI PENELITIAN}

Percobaan ini menggunakan metode Rancangan Acak Kelompok (RAK) dengan pupuk kompos kotoran kelelawar sebagai perlakuan terdiri dari 5 taraf perlakuan yaitu:
$\mathrm{N}_{0}=$ Tanpa pupuk kompos kotoran kelelawar, $\mathrm{N}_{1}=1 \mathrm{~kg}$ pupuk kompos kotoran kelelawar per $\mathrm{m}^{2} \mathrm{~N}_{2}=2 \mathrm{~kg}$ pupuk kompos kotoran kelelawar per $\mathrm{m}^{2} \mathrm{~N}_{3}=3 \mathrm{~kg}$ pupuk kompos kotoran kelelawar per $\mathrm{m}^{2} \mathrm{~N}_{4}=4 \mathrm{~kg}$ pupuk kompos kotoran kelelawar per $\mathrm{m}^{2}$ Jumlah tanaman dalam percobaan ini adalah adalah 5 taraf perlakuan x 5 ulangan x 4 tanaman dalam tiap petak percobaan $=100$ tanaman.

\section{Bahan dan Alat Penelitian}

Bahan yang digunakan dalam penelitian ini adalah benih jagung, kotoran Kelelawar, tanah Podsolik Merah Kuning . Alat yang digunakan dalam penelitian ini adalah parang, cangkul, drum atau tong plastik,, gergaji, tugal, triplek, gunting, timbangan, ember, gembor berkapasitas 5 liter, meteran, kamera digital.

\section{Waktu dan Tempat Penelitian}

Penelitian ini dilaksanakan di Kecamatan Sintang. Penelitian ini dilaksanakan mulai Juni sampai September 2018. 
Pengaruh Pupuk Kompos Kotoran Kelelawar Terhadap Pertumbuhan Dan Hasil Tanaman Jagung Manis (Zea mays saccharata Sturt) Pada Tanah PMK

\section{HASIL DAN PEMBAHASAN}

\section{Hasil Penelitian}

\section{Tinggi Tanaman}

Hasil analisis ragam pengaruh kompos kotoran kelelawar terhadap tinggi tanaman jagung dapat dilihat pada Tabel 1.

Tabel 1. Analisis Ragam Pengaruh Pupuk Kompos Kotoran Kelelawar Terhadap Tinggi Tanaman Jagung Manis (Cm).

\begin{tabular}{lcccccc}
\hline \multirow{1}{c}{ SK } & \multirow{2}{*}{ DB } & \multirow{2}{*}{ JK } & KT & F-hit & \multicolumn{2}{c}{ F-Tabel } \\
\hline Kelompok & 4 & 328,33 & 82,08 & $47,72^{* * *}$ & 4,34 & 5,49 \\
Perlakuan & 4 & $3.944,96$ & $1.092,57$ & $635,22^{* *}$ & & \\
Galat & 16 & 27,52 & 1,72 & & & \\
\hline Total & $\mathbf{2 4}$ & $\mathbf{4 . 3 0 0 , 8 1}$ & KK $=\mathbf{8 , 6 9} \%$ & & & \\
\hline
\end{tabular}

Keterangan: $* *=$ pengaruh sangat nyata

Analisis sidik ragam dalam berpengaruh sangat nyata terhadap

Tabel 1 menunjukkan bahwa peningkatan tinggi tanaman jagung perlakuan pada berbagai dosis pupuk manis pada tanah PMK

kompos kotoran kelelawar

Tabel 2. Uji BNJ Pengaruh Pupuk Kompos Kotoran Kelelawar Terhadap Tinggi Tanaman $(\mathrm{Cm})$.

\begin{tabular}{cccccc}
\hline Perlakuan & Rerata & \multicolumn{3}{c}{ Selisih } \\
\hline $\mathbf{N}_{\mathbf{0}}$ & $134,80 \mathrm{a}$ & & & \\
$\mathbf{N}_{\mathbf{1}}$ & $143,55 \mathrm{~b}$ & $8,75^{* *}$ & & \\
$\mathbf{N}_{\mathbf{2}}$ & $147,90 \mathrm{c}$ & $13,10^{* *}$ & $4,35^{* *}$ & \\
$\mathbf{N}_{\mathbf{3}}$ & $157,60 \mathrm{~d}$ & $22,80^{* *}$ & $14,05^{* *}$ & $9,70^{* *}$ & \\
$\mathbf{N}_{\mathbf{4}}$ & $173,45 \mathrm{e}$ & $38,65^{* *}$ & $29,90^{* *}$ & $25,55^{* *}$ & $15,85^{* *}$ \\
\hline \multicolumn{5}{c}{$\mathbf{S E}=\mathbf{0 , 2 6}$} \\
\hline $\mathbf{Q - 0 , 0 5}=\mathbf{4 , 3 4}$ & \multicolumn{5}{c}{ BNJ 0,05 = 1,14 } \\
$\mathbf{Q - 0 , 0 1}=\mathbf{5 , 4 9}$ & \multicolumn{5}{c}{ BNJ 0,01 = 1,44 } \\
\hline
\end{tabular}

Keterangan: $* *=$ beda sangat nyata

Hasil uji BNJ terhadap tinggi tanaman jagung manis menunjukkan bahwa semakin tinggi dosis pupuk kompos kotoran kelelawar yang diberikan maka pertumbuhan tinggi tanaman jagung manis akan semakin meningkat, perlakuan pada dosis 4 $\mathrm{kg}$ per $\mathrm{m}^{2}$ menghasilkan tinggi 
Pengaruh Pupuk Kompos Kotoran Kelelawar Terhadap Pertumbuhan Dan Hasil Tanaman Jagung Manis (Zea mays saccharata Sturt) Pada Tanah PMK

tanaman yang tertinggi dibanding perlakuan $3 \mathrm{~kg}$ per $\mathrm{m}^{2}, 2 \mathrm{~kg}$ per $\mathrm{m}^{2}, 1$ $\mathrm{kg}$ per $\mathrm{m}^{2}$ dan tanpa perlakuan $0 \mathrm{~kg}$ per $\mathrm{m}^{2}$.
2. Diameter Batang

Hasil analisis ragam pengaruh kompos kotoran kelelawar terhadap diameter batang $\mathrm{j}$ dapat dilihat pada Tabel.3

Tabel 3. Analisis Ragam Pengaruh Pupuk Kompos Kotoran Kelelawar Terhadap Diameter Batang Tanaman Jagung Manis $(\mathrm{Cm})$.

\begin{tabular}{lcclcrc}
\hline \multirow{2}{*}{ SK } & \multirow{2}{*}{ DB } & \multirow{2}{*}{ JK } & \multirow{2}{*}{ KT } & F-hit & \multicolumn{2}{c}{ F-Tabel } \\
\hline Kelompok & 4 & 0,02 & 0,04 & $0,03^{\text {ns }}$ & 4,34 & 5,49 \\
Perlakuan & 4 & 0,76 & 0,19 & $11,88^{* *}$ & & \\
Galat & 16 & 0,25 & 0,02 & & & \\
\hline Total & $\mathbf{2 4}$ & $\mathbf{1 , 0 2}$ & KK $=\mathbf{1 1 , 1 3} \%$ & & \\
\hline
\end{tabular}

Keterangan : $\mathrm{ns}=$ tidak ada pengaruh ** = pengaruh sangat nyata

Analisis sidik ragam pada Tabel 3 menunjukkan bahwa perlakuan pada berbagai dosis pupuk kompos kotoran kelelawar berpengaruh sangat nyata terhadap peningkatan diameter batang tanaman jagung manis

Tabel 4. Uji BNJ Pengaruh Pupuk Kompos Kotoran Kelelawar Terhadap Diameter Batang

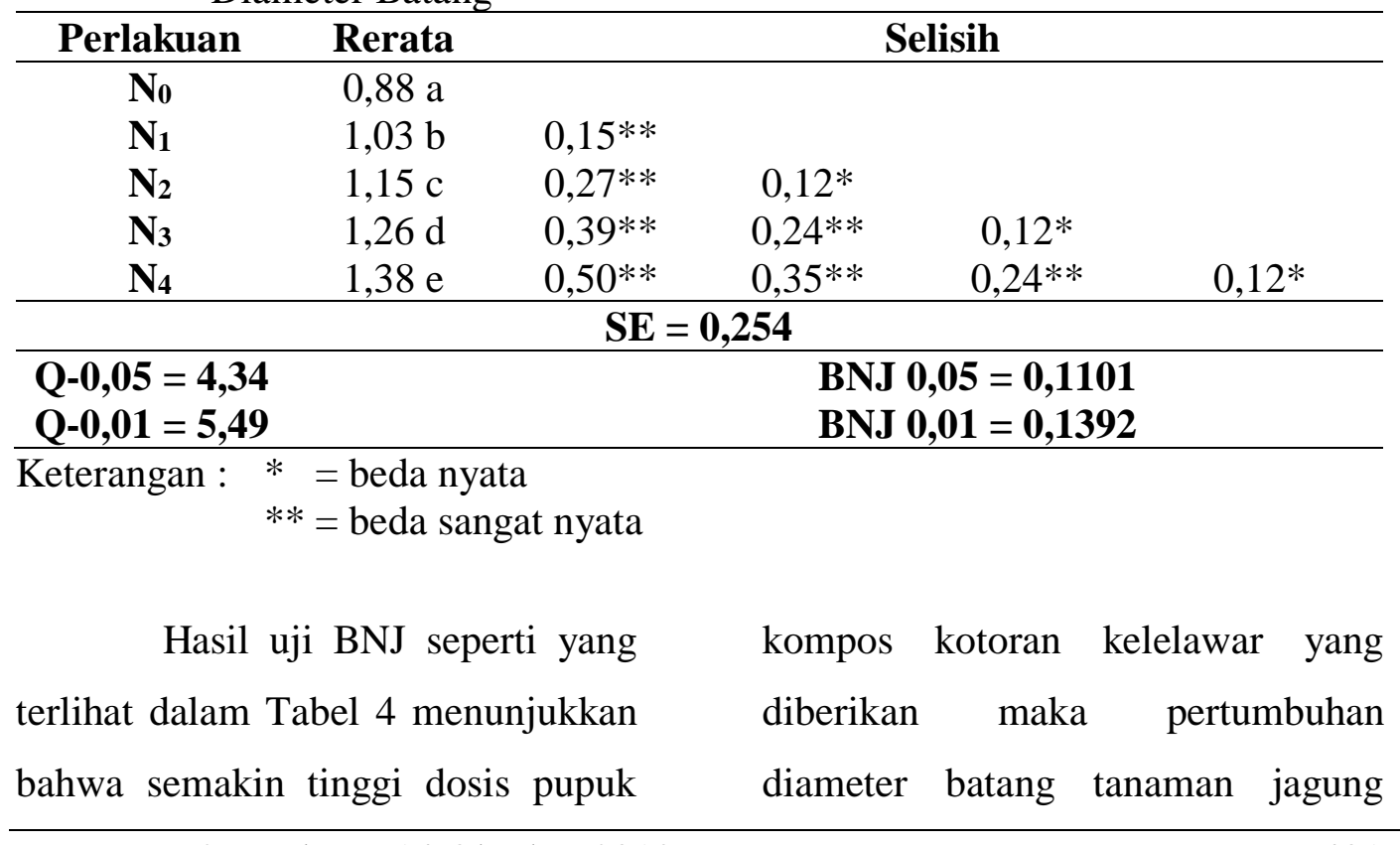


Pengaruh Pupuk Kompos Kotoran Kelelawar Terhadap Pertumbuhan Dan Hasil Tanaman Jagung Manis (Zea mays saccharata Sturt) Pada Tanah PMK

manis akan semakin meningkat, perlakuan yang menghasilkan diameter batang terbesar yaitu pada dosis $4 \mathrm{~kg}$ per $\mathrm{m}^{2}$. perlakuan pada dosis $3 \mathrm{~kg}$ per $\mathrm{m}^{2}, 2 \mathrm{~kg}$ per $\mathrm{m}^{2}$, berbeda nyata dengan perlakuan dosis $1 \mathrm{~kg}$ per $\mathrm{m}^{2}$
3. Berat Tongkol

Hasil analisis ragam pengaruh kompos kotoran kelelawar terhadap berat tongkol dapat dilihat pada Tabel.5

Tabel 5. Analisis Ragam Pengaruh Pupuk Kompos Kotoran Kelelawar Terhadap Berat Tongkol Tanaman Jagung (G).

\begin{tabular}{lcccccc}
\hline \multirow{1}{c}{ SK } & DB & JK & KT & F-hit & \multicolumn{2}{c}{ F-Tabel } \\
\cline { 6 - 7 } Kelompok & 4 & 230,60 & 57,65 & $2,51^{\text {ns }}$ & 4,34 & 5,49 \\
Perlakuan & 4 & 5210,43 & 1302,61 & $56,77^{* *}$ & & \\
Galat & 16 & 367,10 & 22,94 & & & \\
\hline Total & $\mathbf{2 4}$ & $\mathbf{5 8 0 8 , 1 3}$ & $\mathbf{K K}=\mathbf{4 , 7 1}$ & & & \\
\hline Keterangan & $:$ ns & $=$ & tidak ada pengaruh & & & \\
& $* *$ & $=$ & pengaruh sangat nyata & &
\end{tabular}

Analisis sidik ragam yang terlihat dalam Tabel 5 menunjukkan bahwa perlakuan pada berbagai dosis pupuk kompos kotoran kelelawar berpengaruh sangat nyata terhadap peningkatan berat tongkol tanaman jagung manis dan tidak berpengaruh pada berbagai kelompok tanaman jagung manis.

Tabel 6 Uji BNJ Pengaruh Pupuk Kotoran Kelelawar Terhadap Berat Tongkol Tanaman Jagung (G).

\begin{tabular}{cccccc}
\hline Perlakuan & Rerata & \multicolumn{2}{c}{ Selisih } \\
\hline $\mathbf{N}_{\mathbf{0}}$ & $107,65 \mathrm{a}$ & & \\
$\mathbf{N}_{\mathbf{1}}$ & $119,50 \mathrm{~b}$ & $11,85^{* *}$ & & \\
$\mathbf{N}_{\mathbf{2}}$ & $130,15 \mathrm{c}$ & $22,50^{* *}$ & $10,65^{* *}$ & \\
$\mathbf{N}_{\mathbf{3}}$ & $138,20 \mathrm{~d}$ & $30,55^{* *}$ & $18,70^{* *}$ & $8,05^{* *}$ & \\
$\mathbf{N}_{\mathbf{4}}$ & $149,25 \mathrm{e}$ & $41,60^{* *}$ & $29,75^{* *}$ & $19,10^{* *}$ & $11,05^{* *}$ \\
\hline \multicolumn{5}{c}{$\mathbf{S E}=\mathbf{0 , 9 6}$} \\
\hline $\mathbf{Q - 0 , 0 5}=\mathbf{4 , 3 4}$ & \multicolumn{5}{c}{$\mathbf{B N J ~ 0 , 0 5}=\mathbf{4 , 1 6}$} \\
$\mathbf{Q - 0 , 0 1}=\mathbf{5 , 4 9}$ & & & BNJ 0,01 $=\mathbf{5 , 2 6}$ \\
\hline
\end{tabular}

Keterangan : $* *=$ beda sangat nyata 
Pengaruh Pupuk Kompos Kotoran Kelelawar Terhadap Pertumbuhan Dan Hasil Tanaman Jagung Manis (Zea mays saccharata Sturt) Pada Tanah PMK

Hasil uji BNJ menunjukkan
bahwa perlakuan dengan dosis $4 \mathrm{~kg}$
per $\mathrm{m}^{2}$ pupuk kompos kotoran
kelelawar menghasilkan berat
tongkol tanaman yang lebih tinggi
dibanding perlakuan dengan dosis 3
kg per $\mathrm{m}^{2}, 2 \mathrm{~kg}$ per $\mathrm{m}^{2}, 1 \mathrm{~kg}$ per $\mathrm{m}^{2}$
dan tanpa perlakuan $0 \mathrm{~kg}$ per $\mathrm{m}^{2}$.
Pemberian pupuk kompos kotoran
kelelawar terhadap berat tongkol
tanaman jagung manis menunjukkan
bahwa semakin tinggi dosis
perlakuan yang diberikan maka berat
tongkol tanaman jagung manis akan
semakin meningkat

\section{Pembahasan}

Hasil penelitian menunjukkan bahwa pemberian pupuk kompos kotoran kelelawar berpengaruh terhadap tinggi tanaman, diameter batang, dan berat tongkol. Hal ini menunjukkan bahwa pupuk kompos kotoran kelelawar dapat meningkatkan pertumbuhan dan hasil tanaman jagung. Peningkatan pertumbuhan dan hasil akibat pemberian pupuk kompos kotoran kelelawar diduga menyebabkan hara $\mathrm{N}$, P, dan $\mathrm{K}$ menjadi lebih tersedia bagi tanaman, karena pupuk kompos kotoran kelelawar mempunyai kandungan utamanya adalah $\mathrm{N}, \mathrm{P}$, dan K (Lingga dan Marsono, 2012:36-37). Puspadewi, dkk (2016:210) menjelaskan bahwa unsur $\mathrm{N}$, P, dan K merupakan salah satu unsur hara esensial bagi tanaman, lebih lanjut dijelaskan peningkatan pertumbuhan dan hasil tanaman jagung manis pada tanah PMK akibat pemberian pupuk kompos kotoran kelelawar tidak terlepas dari peran fisiologis $\mathrm{N}, \mathrm{P}$, dan $\mathrm{K}$ karena merupakan unsur hara yang diperlukan dalam metabolisme tanaman.

Hasil penelitian ini menunjukkan bahwa semakin tinggi dosis pupuk kompos kotoran kelelawar yang diberikan maka pertumbuhan tanaman semakin meningkat. Hal ini diduga pemberian pupuk kompos kotoran kelelawar selain sebagai bahan organik yang berperan dalam memperbaiki sifat fisik tanah PMK, namun juga sebagai suplai hara karena mengandung 6,76\% N, 185,18 ppm $\mathrm{P}$, dan $0,55 \mathrm{~K}$ yang mampu meningkatkan pertumbuhan tinggi, diameter batang, dan berat tongkol 
Pengaruh Pupuk Kompos Kotoran Kelelawar Terhadap Pertumbuhan Dan Hasil Tanaman Jagung Manis (Zea mays saccharata Sturt) Pada Tanah PMK

tanaman jagung manis. Hal ini sejalan dengan Fattah dalam Irmansyah, dkk (2015:240) yang menyatakan bahwa pupuk kompos kotoran kelelawar berperan dalam menyediakan unsur hara mineral bagi tanaman, mengembalikan kesimbangan tanah dan mempertahankan unsur hara lebih lama sehingga dapat mendukung pertumbuhan dan hasil tanaman jagung secara optimal.

Mauke, dkk menjelaskan bahwa $\mathrm{N}$ merupakan bahan penyusun asam amino, amida, nukleotida, dan nukleoprotein, serta esensial untuk pembelahan sel, perkembangan sel, oleh karenanya unsur $\mathrm{N}$ penting untuk pertumbuhan tanaman. Nitrogen merupakan bagian dari semua sel hidup, $\mathrm{N}$ di dalam tanaman berfungsi sebagai komponen utama protein, hormone, klorofil, vitamin, dan enzim-enzim esensial untuk pertumbuhan tanaman (Hariyadi 2014:60). Hal ini sejalan dengan Tirta (2012:83) yang menyatakan bahwa nitrogen adalah unsur hara makro yang sangat diperlukan tanaman dalam fase pertumbuhan vegetatif dan mempercepat fase pemasakan buah.

Sitorus, dkk (2015: 67) menjelaskan bahwa $\mathrm{P}$ merupakan bagian yang esensial dari berbagai gula posfat yang amat berperan sebagai reaksi metabolisme tumbuhan. Ozi, dkk (2015:29) menjelaskan bahwa unsur $\mathrm{P}$ juga merupakan bahan penyusun fosfolipid, senyawa memegang peranan penting dalam integritas membran sel. Lebih lanjut dijelaskan bahwa usur hara P sangat diperlukan dalam pertumbuhan akar dan perkembangan biji tanaman. Sejalan dengan hal tersebut, Setiawati, dkk (2012:43) menjelaskan bahwa fungsi paling utama unsur $\mathrm{P}$ adalah keterlibatannya dalam penyimpanan dan transfer energi di dalam tanaman sehingga unsur hara $\mathrm{P}$ sangat penting sebagai sumber energi untuk pertumbuhan dan metabolisme tanaman seperti pembelahan sel, respirasi dan proses fotosintesis yang akan berpengaruh pada peningkatan berat tongkol tanaman jagung manis.

Ozi, dkk (2015:

menjelaskan bahwa unsur $\mathrm{K}$ 
Pengaruh Pupuk Kompos Kotoran Kelelawar Terhadap Pertumbuhan Dan Hasil Tanaman Jagung Manis (Zea mays saccharata Sturt) Pada Tanah PMK

berperan sebagai aktivator enzim. Nainggolan dan Hapsoh (2017: 1-15) menjelaskan bahwa unsur $\mathrm{K}$ membantu memelihara potensial osmotik sel dan menjaga kehilangan air dari dalanm sel tumbuhan. Lingga dan Marsono (2012:8) menjelaskan bahwa unsur $\mathrm{K}$ berperan memacu pembentukan protein dan karbohidrat, memperkuat pertumbuhan tanaman, menjaga bunga dan buah tidak mudah rontok serta meningkatkan resistensi tanaman terhadap serangan penyakit.

Menurut Utami (2014:23), pemberian pupuk kompos kotoran kelelawar pada tanah PMK sangat berperan dalam meningkatkan respirasi tanah dan biomassa mikroorganisme tanah, semakin banyak pupuk kompos kotoran kelelawar yang ditambahkan semakin tinggi populasi dan aktivitas mikroorganisme tanah. Hal ini sejalan dengan Meity (2012: 61) menjelaskan bahwa pupuk kompos kotoran kelelawar yang ditambahkan kedalam tanah PMK menyediakan zat pengatur tumbuh tanaman yang memberikan keuntungan bagi pertumbuhan tanaman seperti vitamin, asam amino, auksin, dan giberelin yang terbentuk melalui dekomposisi pupuk kompos kotoran kelelawar.

Atmojo (2013:46) pupuk kompos kotoran kelelawar dapat menyediakan unsur hara makro dan mikro, mengandung asam humat (humus) yang mampu meningkatkan kapasitas tukar kation pada tanah pmk, penambahan pupuk kompos kotoran kelelawar pada tanah PMK juga dapat membantu meningkatkan pH tanah. Lebih lanjut dijelaskan pemberian pupuk kompos kotoran kelelwar pada tanah PMK dengan kandungan Al tertukar tinggi, akan menyebabkan peningkatan $\mathrm{pH}$ tanah, karena asam-asam pupuk kompos kotoran kelelwar hasil dekomposisi akan mengikat $\mathrm{Al}$ membentuk senyawa komplek (khelat), sehingga Al tidak terhidrolisis lagi.

\section{KESIMPULAN DAN SARAN}

\section{Kesimpulan}

Hasil dari penelitian ini disimpulkan bahwa:

1. Pemberian pupuk kompos kotoran kelelawar pada tanah 
Pengaruh Pupuk Kompos Kotoran Kelelawar Terhadap Pertumbuhan Dan Hasil Tanaman Jagung Manis (Zea mays saccharata Sturt) Pada Tanah PMK

PMK berpengaruh nyata
terhadap pertumbuhan tinggi
tanaman, diameter batang, dan
berat tongkol tanaman jagung
manis
2. Pertumbuhan tertinggi akibat
pemberian pupuk kompos
kotoran kelelawar dicapai pada
dosis 4 kg per m ${ }^{2}$, pada dosis
tersebut menghasilkan rerata
tinggi tanaman $171,5 \mathrm{~cm}$, rerata
diameter batang terbesar 1,38,
dan rerata berat tongkol terbesar
149,25 g per tanaman.

\section{Saran}

1. Pupuk kompos kotoran kelelawar dapat digunakan untuk meningkatkan pertumbuhan dan hasil tanaman jagung manis.

2. Dosis $4 \mathrm{~kg}$ per $\mathrm{m}^{2}$ dapat diterapkan dalam meningkatkan pertumbuhan dan hasil jagung manis pada tanah PMK

\section{DAFTAR PUSTAKA}

Arif, Amrizal. 2012. Pengaruh Pemberian Pupuk Organik Guano Dan Tithonia (Tithonia Diversifolia) Terhadap Pertumbuhan Dan Hasil Tanaman Jagung Manis (Zea Mays Saccharata Sturt).
Jurnal. Padang: Fakultas Pertanian Universitas Andalas. Diunduh pada tanggal 12 Oktober 2017.

Atmojo, Suntoro Wongso. 2013. Peranan Bahan Organik Terhadap Kesuburan Tanah Dan Upaya Pengelolaannya. Tesis. Surakarta: Universitas Sebelas Maret. Diakses tanggal 5 Agustus 2018.

Badan Pusat Statistik Kabupaten Sintang. 2015. Kabupaten Sintang Dalam Angka. Sintang: BPS Kabupaten Sintang. Diakses pada tanggal 10 semptember 2017).

Billi, Stepanus. 2014. Serapan Nitrogen Oleh 20 Varietas Jagung Manis Pada Sistem Pertanian Organik. Skripsi. Bengkulu:Fakultas Pertanian Universitas Bengkulu. Diakses pada tanggal 20 September 2017.

Doddy, Dongoran. 2009. Respon Pertumbuhan dan Produksi Tanaman Jagung Manis (Zea Mays Saccharata Sturt) Terhadap Pemberian Pupuk Cair TNF dan Pupuk Kandang Ayam. Skripsi. Medan: Fakultas Pertanian Universitas Sumatera Utara. Diakses pada tanggal 31 oktober 2017.

Evan, Sanjaya., Gantar Sitanggang, dan Damanik. 2014. Perbaikan Sifat Fisik Dan Kimia Tanah Podsolik Merah Kuning Kecamatan Pancur Batu Dengan Pemberian Pupuk Organik Supernasa Dan 
Pengaruh Pupuk Kompos Kotoran Kelelawar Terhadap Pertumbuhan Dan Hasil Tanaman Jagung Manis (Zea mays saccharata Sturt) Pada Tanah PMK

\begin{tabular}{|c|c|}
\hline $\begin{array}{lr}\text { Rockphosphit } & \text { Serta } \\
\text { Pengaruhnya } & \text { Terhadap }\end{array}$ & $\begin{array}{l}\text { Pupuk KCl. Jurnal Online } \\
\text { Agroekoteknologi Vol.3 No.1. }\end{array}$ \\
\hline $\begin{array}{l}\text { Produksi Tanaman Jagung } \\
\text { (Zea Mays }\end{array}$ & $\begin{array}{l}\text { Diakses tanggal } 26 \text { Agustus } \\
2018 \text {. }\end{array}$ \\
\hline
\end{tabular}
Agroekoteknologi. Vol.2, No.2. Diakses pada tanggal 25 oktober 2017.

Evi, Dwi Nur Hayanti., Yuliani., dan Herlina Fitrihidayati. 2014. Penggunaan Kompos Kotoran Kelelawar (Guano) untuk Meningkatkan Pertumbuhan Tanaman Kacang Tanah (Arachis hypogaea). Journal Lentera Bio. Vol. 3 No. 1. Diakses tanggal 12 september 2017.

Gasperss. $1999 . \quad$ Metode Perancangan Percobaan. Bandung: Armico. Diakses tanggal 14 september 2017.

Hanafiah, K.A. 2014. Rancangan Percobaan Teori dan Aplikasi. Jakarta: PT Raja Grafindo Persada.

Hariyadi. 2014. Aplikasi Takaran Guano Walet Sebagai Amelioran Dengan Interval Waktu Pemberian Terhadap Pertumbuhan dan Hasil Cabai Rawit (Capsicum frustescents L.) Pada Tanah Gambut Pedalaman. Jurnal Agroscientiae Vol 1 No 9. Diakses tanggal 7 Agustus 2018.

Irmansyah., Ginting., dan Sevinda. 2015. Respons Pertumbuhan dan Produksi Tanaman Jagung Hibrida Terhadap Pemberian Kompos Limbah Jagung dan

Lingga., dan Marsono. 2012. Petunjuk Penggunaan Pupuk. Jakarta: Penebar Swadaya.

Mauke, Stenli., Bahua, Muhammad., dan $\quad 2015$. Pertumbuhan dan Produksi Tanaman Jagung Manis (Zea Mays Sacaratha L.) Melalui Pemberian Pupuk Urea dan Phonska. JATT Volume 4 Nomor 1. Diakses tanggal 4 Agustus 2018.

Martajaya, Muhammad., Lily, Agustina., dan Syekhfani. 2010. Metode Budidaya Organik Tanaman Jagung Manis di Tlogomas, Malang. Jurnal Pembangunan dan Alam Lestari. Vol. 1 No.1 Tahun 2010. Diunduh tanggal 17 September 2017.

Meity, Polli. 2012. Hasil Tanaman Jagung Manis (Zea Mays Saccharata L.) PadaBeberapa Dosis Pupuk Organik. Eugenia Volume 18 No. 1. Diunduh tanggal 30 Juli 2018.

Nainggolan, Gideon. dan Hapsoh. 2017. Respons Tanaman Jagung Manis (Zea Mays Saccharata Sturt) Yang Diberi Pupuk Guano Dengan NPK Di Lahan Gambut. Jom Feperta Vol 4 No.2. Diakses tanggal 6 Agustus 2018. 
Pengaruh Pupuk Kompos Kotoran Kelelawar Terhadap Pertumbuhan Dan Hasil Tanaman Jagung Manis (Zea mays saccharata Sturt) Pada Tanah PMK

Ozi, Nurhasanah.,Yetti, Husna, Erlida, $\quad$ Ariani. 2015. Pemberian Kombinasi Pupuk Hijau Azolla Pinnata Dengan Pupuk Guano Terhadap Pertumbuhan Dan Produksi Tanaman Pakchoy (Brassica Chinensis L.). Prossiding. Jom Faperta Vol. 2 No 1. Fakultas Pertanian Universitas Riau. Diunduh tanggal 12 Oktober 2017.

Puspadewi., Sutari.W., dan Kusumiyati. 2016. Pengaruh konsentrasi pupuk organik cair (POC) dan dosis pupuk N,P, K terhadap pertumbuhan dan hasil tanaman jagung manis (Zea mays L. var Rugosa Bonaf) kultivar Talenta. Jurnal Kultivasi Vol. 15 No 3. Diakses tanggal 25 Agustus 2018.

Redman, Kesema. 2016. Pengaruh Pemberian Ekstrak Daun Lamtoro Dan Pupuk Nitrogen Terhadap Pertumbuhan Dan Produksi Tanaman Jagung Manis (Zea Mays L. Saccharata Sturt.). Skripsi. Bandar Lampung: Fakultas Pertanian Universitas Lampung. Diakses pada tanggal 29 Oktober 2017. 